\title{
Isolation and Identification of Wild Isolate of Newcastle Disease Virus from Broiler Farm in Diyala Province: Virological and Histopathological Study
}

\author{
Amer Khazaal Al-Azawy, Karim Sadun Al-Ajeeli and Alaa Ismail \\ Department of Microbiology, College of Veterinary Medicine, University of Diyala. \\ E-mail: amer alazawy@yahoo.com \\ Received: $18 / 3 / 2018$ \\ Accepted: $16 / 5 / 2018$ \\ Publishing:31/1/2019

\section{Summary}

A broiler poultry farm of six weeks old, vaccinated with LaSota Newcastle disease virus vaccine. The flock was infected with a virulent Newcastle disease virus with mortality rate up to $90 \%$. Newcastle disease virus was isolated from infected birds in embryonated chicken eggs and identified by haemagglutination inhibition test using hyperimmune serum prepared against LaSota viral vaccine. Median Death Time, Intracerebral Pathogenicity Index and Intravenous Pathogenicity Index proved that the virus was a virulent viscerotropic isolate. In experimental infection, broilers were vaccinated twice with LaSota strain, the level of anti-Newcastle disease virus IgG was checked by Enzyme-linked immunosorbent assay test pre and post vaccination and the birds were challenged with the same isolated virulent isolate at 35 days old, the virus was inoculated by oral and nostril routs. The challenge virus produced the same sever clinical signs and the mortality rate reached up to $70 \%$. Tissue samples were collected from intestine, kidneys, lung, trachea, spleen, liver, and the brain of the experimentally infected broilers, they showed sever pathological changes. It seems that vaccination with commercial available vaccine could not produce enough protection against virulent circulating Newcastle disease virus strains, accordingly preparation of viral vaccine from local virulent isolate is recommended after attenuation or inactivation.

Keywords: Newcastle Disease Virus, LaSota, Broilers.

\section{Introduction}

Newcastle disease (ND) of birds is one of the most contagious and infectious disease that cause an important economic losses in poultry industry among its worldwide distribution. Fowls, pigeons, sparrows, turkeys and most other avian species are susceptible to the infection with ND. The causative agent is a virus of single stranded RNA, negative polarity, and not segmented (1 and 2). Avian paramyxovirus-1 or Newcastle disease virus was classified within the genus Avulavirus. This genus was grouped in the family Paramyxoviridae of the order Mononegaviralis (1and 3) .

FAO (4) reported that ND is the major threat to poultry industry, and the high morbidity and mortality in infected poultry birds were attributed to the variations in Newcastle disease virus (NDV) strains. NDV isolates were grouped into five serotypes depending on their virulence and clinical signs, these are asymptomatic unapparent intestinal infection that are associated with subclinical signs clear symptoms, lentogenic strains are characterized by unapparent or subclinical, and mild respiratory signs, with little drop in egg production, nervous signs and negligible mortality. Mesogenic strain are characterized with rare respiratory and nervous signs, if present it appeared as mild signs with coughing (5),young birds were more susceptible in comparison to adult and might be show considerable mortality rate up to $10 \%$, loss of body weight, late nervous signs and decrease in egg production in layers might be observed (6).

Neurotropic velogenic are appeared suddenly, with acute respiratory signs, unappetence, nervous signs and drop in egg production of layer and viscerotropic velogenic are characterized by severe intestinal haemorrhagic lesions, clear depression, and dehydration, the birds 
collapsed due to severe greenish yellow diarrhea(6). Drop in egg production in layers, increased respiration and high mortality rate up to $90 \%$ were also observed. Some birds died suddenly or showed nervous signs especially those survived the infection(7). Recently many vaccinated broiler farms with LaSota virus were infected with wild strain of NDV that caused a high mortality rate up to $70 \%$, accordingly this study was designed to isolate and identify a wild NDV from infected broiler farms of Diyala province.

\section{Materials and Methods}

A poultry farm of six weeks old 10,000 broilers was infected with NDV, the clinical signs were observed as severe greenish diarrhea, depression of birds, dehydration, drooping wings, in appetence, and swelling of eyes. The mortality started with $5-10 \%$ and reached up $90 \%$ within few days when 800 birds died daily. The broilers were vaccinated twice with LaSota NDV vaccine (Nobilis ND Clone 30 Intervet company -Holland, each dose contains at least 106 EID50 of the ND strain Clone 30) at two and three weeks old. Post-mortem finding showed severe hemorrhagic lesions in intestinal mucosa (bloody intestine), Proventricular mucosa showed petechial hemorrhages, congestion and mucoid exudates in the trachea, opacity and thickening of air sac were also observed.

Samples were collected from intestinal tissues, lungs, trachea, spleen, kidneys, and air sacs. The samples were collected in aseptic condition and transferred immediately to virology laboratory; College of Veterinary Medicine, University of Diyala, in bottles containing phosphate buffered saline and antibiotic antimycotic and anti PPLO. Samples were processed by the use of sterile morters and pestles, and sterile sands to make $10 \%$ suspension. The mixture was centrifuged in cold centrifuged at $3000 \mathrm{rpm}$ for 15 minutes at $4^{\circ} \mathrm{C}$. The supernatant was collected and the sediment was condemned and discarded. The collected supernatant of different processed tissues were mixed with antibiotic, antimycotic and anti PPLO and left for 1 houre in room temperature.

Isolation of the virus was performed in embryonated hen eggs of 9 days old embryo.
For this purpose 10 eggs were used, 6 for inoculation and 4 as control. Stock processed sample was inoculated in allantoic cavity using $0.1 \mathrm{ml}$ of processed sample for each egg. Control embryonated chicken eggs were inoculated by the same method but by the use of sterile normal saline. All opened shells were closed by wax and the eggs were incubated at $37^{\circ} \mathrm{C}$ and observed daily. Any death of embryos 24 hours post infection was excluded and regarded as non-specific death.

Hyperimmune serum against NDV was prepared in rabbits according to the method described by (8). For this purpose six rabbits were raised, four for hyperimmune serum preparation and two used as control. Rabbits were inoculated intramuscularly with one $\mathrm{ml}$ of LaSota NDV (Ceva New L® NDV LaSota strain/ Lentogenic. Lyophilized vial of 1000 dose, Ceva Company -France) vaccine dissolved in sterile distilled water. The inoculation was repeated weekly for four weeks. This was followed by collection of blood and separation of serum that was kept at $-20^{\circ} \mathrm{C}$ until used.

Inoculated eggs that contained dead embryo were removed, opened and the presence of the virus was checked by slide hemagglutination (HA) test by the use of one drop of $4 \%$ avian RBCs in normal saline and one drop of inoculated allantoic fluid on clean glass slide. Positive HA allnatoic fluid was collected, pooled together and kept at $-30^{\circ} \mathrm{C}$ until used. This was followed by titration of the virus by plate hemagglutination as usual by the use of double 2-folds serial dilution of the virus and $1 \%$ of avian RBCs in sterile normal saline. Identification of the virus isolate was carried by the use of plate hemagglutination inhibition (HI) test. In this test, $4 \mathrm{HA}$ units $/ 0.1 \mathrm{ml}$ of isolated virus was used against 2-folds serial dilution of anti LaSota virus vaccine hyperimmune serum prepared in rabbits.

It was measured in hours after inoculation of hen's eggs containing 9-11 days old embryo. Serial dilutions of NDV were used for such inoculation. Inoculated emryonated eggs were incubated and observed in hours for death of embryos. Velogenic strain of NDV caused the death of embryos in less than $60 \mathrm{hrs}$. Lentogenic strains of the same virus were responsible for the death of embryos in more 
than 90 hrs. NDV that caused the death of embryos in more than $60 \mathrm{hrs}$. but less than 90 hrs. was considered mesogenic strain ( 9 and $10)$.

The pathogenicity indices of isolated virus were determined (11)

Intracerebral Pathogenicity index was simply performed as follows: Fresh infective allantoic fluid with a HA titre $>24(>1 / 16)$ was diluted $1 / 10$ in sterile isotonic saline with no additives, such as antibiotics. An amount of $0.05 \mathrm{ml}$ of the diluted virus was injected by the use of sterile tuberculin syringe intracerebrally into each of ten chicks hatched from eggs from an SPF flock. These chicks were 24 hours old. The birds were examined every 24 hours for 8 days.

Intravenous Pathogenicity Index: Fresh infective allantoic fluid with a HA titre $>24$ $(>1 / 16)$ was diluted $1 / 10$ in sterile isotonic saline with no additives, such as antibiotics. An amount of $0.1 \mathrm{ml}$ of the diluted virus was injected by the use of tuberculin syringe, intravenously into each of ten 6-weeks old SPF chickens. Birds were examined at 24hours intervals for 10 days and scored at each observation.

Experimental Infection: Thirty broiler chickens of 35 days old were used for the inoculation with local isolate of NDV, they were vaccinated twice with LaSota virus strain vaccine. Another 10 birds were used as control and kept far from the infected chicken to avoid of transmission possibility of the isolate. The titer of anti NDV IgG in the blood of such birds was determined 3, 14, and 25 days of age by the use of ELISA kit (Synbiotics ProFLOK® PLUS NDV ELISA kit, USA). Experimental chickens were inoculated with $0.1 \mathrm{ml}$ of $1 / 10$ diluted stock virus by nose dropping, and mouth. The control chicks were inoculated by the same method but using allantoic fluid from non-infected embryonated control eggs diluted $1 / 10$ in sterile normal saline. All chickens observed daily to check the clinical signs and mortality. Dead broilers were subjected to postmortem, and tissue samples were collected from lungs, trachea, spleen, liver, kidneys, intestine and brain for virus re-isolation and studying the histopathological changes in infected birds induced by the virus. Re-isolation and identification of the virus from collected and processed samples from infected birds were done as mentioned above.

Tissue samples that were collected from infected birds were subjected to the department of histology and anatomy for preparing paraffin embedded tissues, later they were stained with hematoxiline and eosin stains (12). Stained tissues were examined for histopathological changes induced by the virus.

\section{Results and Discussion}

The virus was isolated in allontoic cavity of embryonated eggs, positively detected by slide HA test. Titrated by the HA plate test and gave a titer of $1024 \mathrm{HAU} / 0.1$. Then the virus was identified as NDV by the use of anti- LaSota hyperimmune serum and HI test. The titer of hyperimmune serum in this test appeared as 216HIU/0.1 $\mathrm{ml}$ of stock serum.

Pathogenicity of the virus and its classification as virulent virus depended on results of the mean death time and pathogenicity indices. The MDT appeared when the dilution 10-10 of the virus killed all the inoculated embryonated eggs within 48 hours. The ELD50 of isolated virus appeared as 10-11.3ELD50/0.1 $\mathrm{ml}$ of the stock virus. ICPI, IVPI and showed the death of all embryonated eggs within less than 60 hours PI. All above mentioned results clearly indicated that the isolated NDV was velogenic virulent isolate. Differentiation between NDV isolates of low and high virulence activity can be done by many pathogenicity tests based on either the use of one day old chicks or 6-10 weeks old chicken ( 9 and 13). These tests were considered as standard pathogenicity parameters (6 and 14).

The IgG antibody level appeared high at 3 days of age and this may be attributed to maternal antibody level in these chicks. This level was highly reduced at 14 days of age and prior to first vaccination. The same can be said to the level of $\operatorname{IgG}$ at the age of 25 days old chicken and also prior to second vaccination (Table, 1). This decrease of antibody level appeared significant $(\mathrm{P}=002)$ when such level compared to level of IgG at 3 and 14 days old. 
Table, 1: IgG antibody titer in experimental group before infection.

\begin{tabular}{|c|c|c|c|c|c|c|c|}
\hline Duration & No. & Mean & SD & SE & DF & F test & P= \\
\hline 3 DAY & 30 & 11361.20 & 3980.16 & 726.67 & 5 & 002.80 & 0.020 \\
\hline 14 DAY & 30 & 3048.77 & 1412.45 & 257.88 & 5 & 021.00 & 0.007 \\
\hline 25 DAY & 30 & 413.10 & 0173.67 & 031.71 & 5 & 100.98 & 0.002 \\
\hline
\end{tabular}

The high level of IgG in the serum of birds at 3 days old might be attributed to maternal antibody levels, antibodies will be transferred vertically to the eggs, and the titer of antibodies in fertilized eggs or one day old chicks was associated to titer of same antibodies of parent layer. Accordingly such level of antibodies must be considered when a vaccination program was attempt (9).The first immunologic response of birds to NDV live vaccination was detected 3rd day post vaccination and reached its maximum level in 1 st or 2 nd week. Reduction in its high peak occurred gradually after 3rd and 4th week post vaccination (15). Moreover, neutralizing antibodies appeared in serum of infected birds 6-10 days PI and reached its maximum 3-4 weeks PI and declined slowly (16). It was shown that HI antibodies in birds recovered from NDV infection lasted for one year. Secondary antibodies were induced if such birds were re-infected or immunized (17). Using of multiple vaccination by using of live vaccine then followed by the use of oil adjuvant vaccine 6 weeks later, induced secondary cell mediated immunity (CMI) but not strong when compared to humoral antibody response in the same birds (18).

In the present study the level of $\operatorname{IgG}$ antibody seemed of no value when such birds were challenged with virulent strain of the virus. Many reports mentioned that the main protective immunity was CMI (19). Contrary, another study proved that CMI was not protective in vaccinated birds against challenge with virulent NDV (15). Presence of certain levels of preexicsting immune responses is not too essential to inhibit the infection but may reduce its severity (15 and 20).
The broilers of the present study were inoculated at 35 days of age and 10 days post second vaccination. Clinical signs appeared 2 days PI as mild nasal discharge, depression, and tachypnea. Conjunctival swellings with red spot on the lymphoid patches of lower eyelids also were observed. The birds also showed inappetence. On the following days the clinical signs developed quickly as tachypnea, severe greenish diarrhea, severe nasal discharge, and depression. Edematous head, paralysis of legs, and head torticollis were also observed on most infected birds. The mortality rate reached $70 \%$ when 21 birds died out of 30 birds of the group .

Many reports mentioned severe respiratory signs mostly associated with aerosol rout. Furthermore, sudden onset of the disease was associated with virulent strains, and sometimes high mortality rate was reported without clinical signs (9 and 21). Appearance of clinical signs 2- 4 days PI, severe respiratory and nervous signs, and a mortality rate that reached up of $100 \%$ in experimental infection with virulent NDV strain also were reported (22). The mortality rate in present study reached $70 \%$ and might be associated to the mild protection of the vaccine .

Postmortem findings of infected birds showed severe hemorrhage in proventriculus, (Fig.1) intestinal mucosa (Fig .2), and enlarged caecal tonsil that appeared edematous, bloody and necrotized (Fig.3). Trachea showed mucosal hemorrhage with severe congestion of mucosal membrane. All samples that were collected from such birds were positive for virus isolation in embryonated eggs and also were identified by $\mathrm{HI}$ test and the use of anti LaSota hyperimmune serum as mentioned above. 


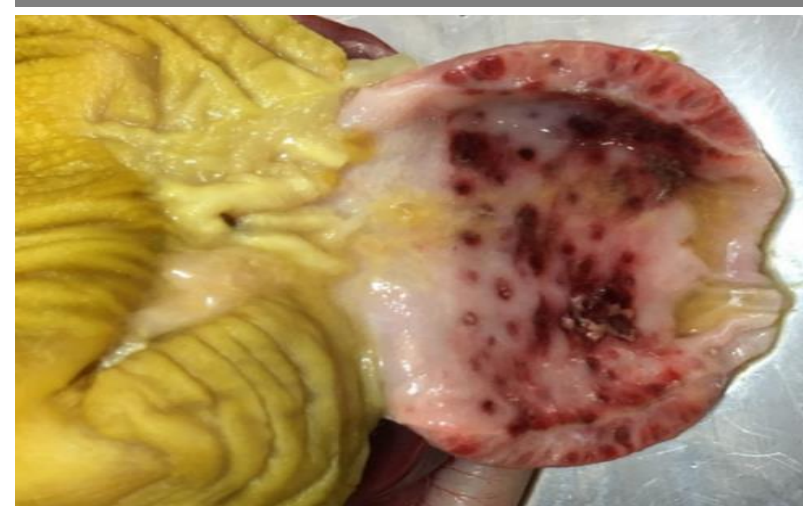

Figure,1: The proventriculus of experimentally infected birds showed severe petechial hemorrhages and necrotizing foci.

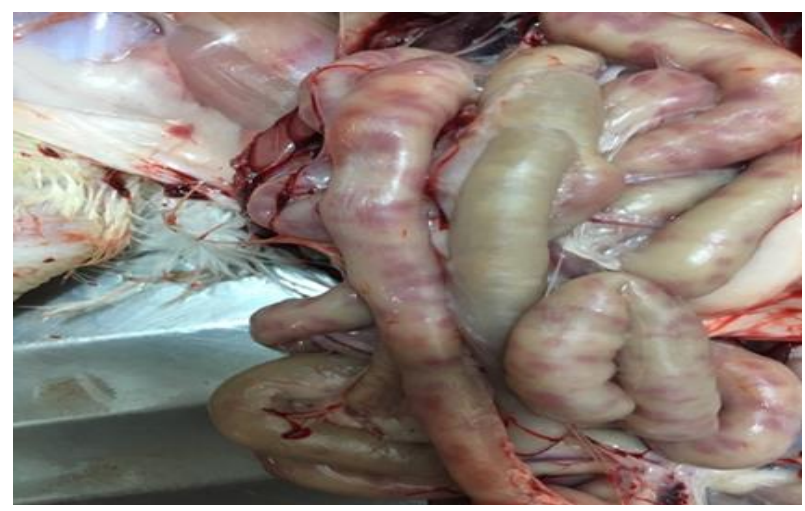

Figure, 2: Intestine from experimentally infected broilers showed clear hemorrhagic foci that appeared dark red from outside vision. Blood contents were appeared clearly in open intestine (the arrow).

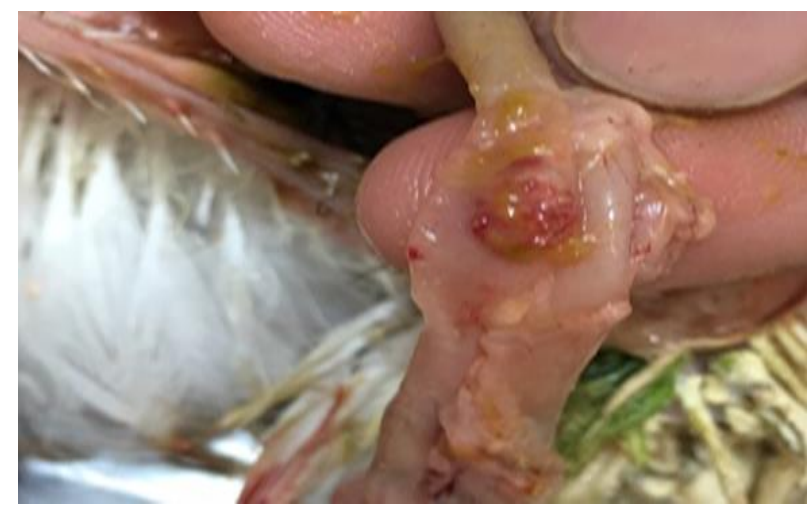

Figure,3: Opened caeca of the broiler intestine showed the edematous inflammation and bloody necrotized foci.

The above mentioned gross lesions were reported by many workers and mostly associated with the infection of birds with virulent strains of NDV (11, 23 and 24).

Histopathological changes were also observed in different organs when $\mathrm{H} \& \mathrm{E}$ stained infected tissues examined microscopically. Kidneys showed hemorrhage, tubular epithelial cell necrosis, and inflammatory cell infiltration in the interstitium (Fig.4).

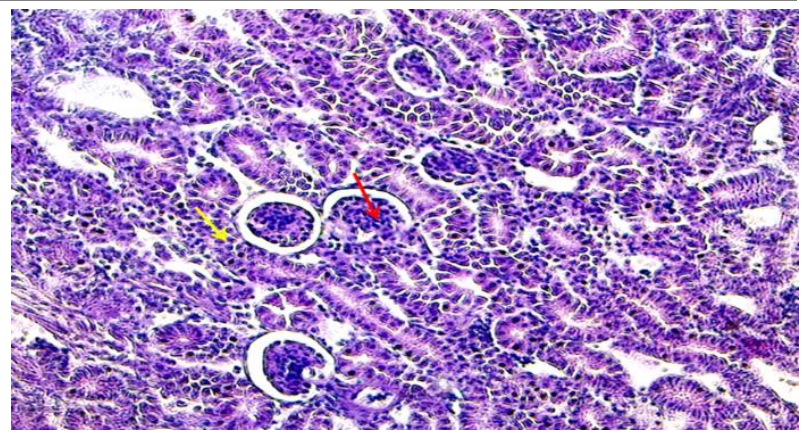

Figure,4: Kidneys showed acute glomerulonephritis due to degeneration changes in the glomeruli (red arrow) and also presence of inflammatory cells around renal tubules (yellow arrow) (H\&E stain).

Tracheal tissue showed deciliation, congestion, hemorrhage, mononuclear inflammatory cell infiltration, and edema at almost every tracheal sample (Fig.5).

\section{A}

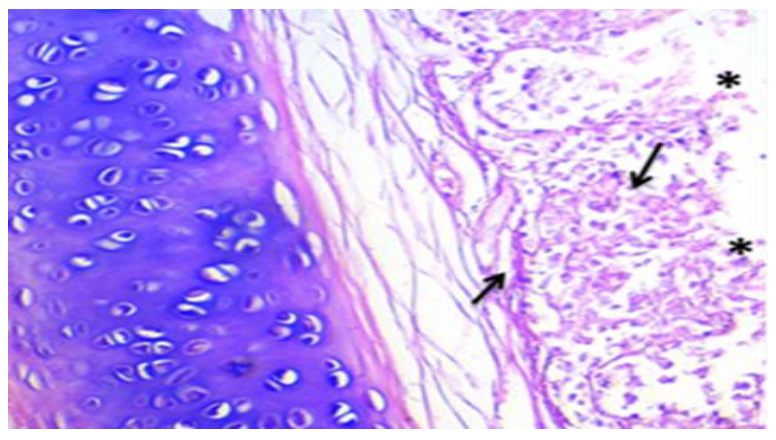

B

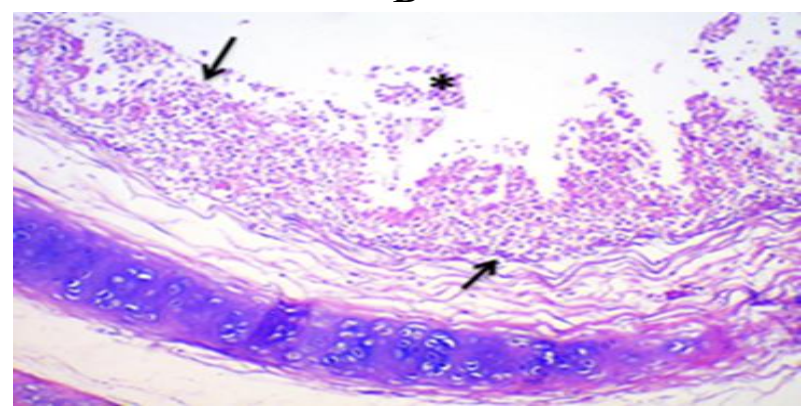

Figure,5: Trachea showed moderate to severe decilliation in the tracheal layer, also severe degeneration in the lamina properia (myofiber). The epithelium appeared hyperplastic and the lamina propria distended (black arrows A\&B) with infiltration of macrophages and lymphocytes into the submucosa and lamina propria, the epithelial cells degenerated and desquamated in tracheal lumens(* A\&B). No mucus glands were detected due to decilliation, and some infiltration by $\mathrm{MNC}$ (H\&E stain).

Microscopic sections of lung tissue stained with $\mathrm{H} \& \mathrm{E}$ showed acute pulmonary edema due to accumulation of fluids and proteins in the alveoli which will lead to expansion of the alveolar wall, also there was interstitial infiltration of mononuclear cell in the lung 
observed around the bronchioles and bronchi (Fig.6).

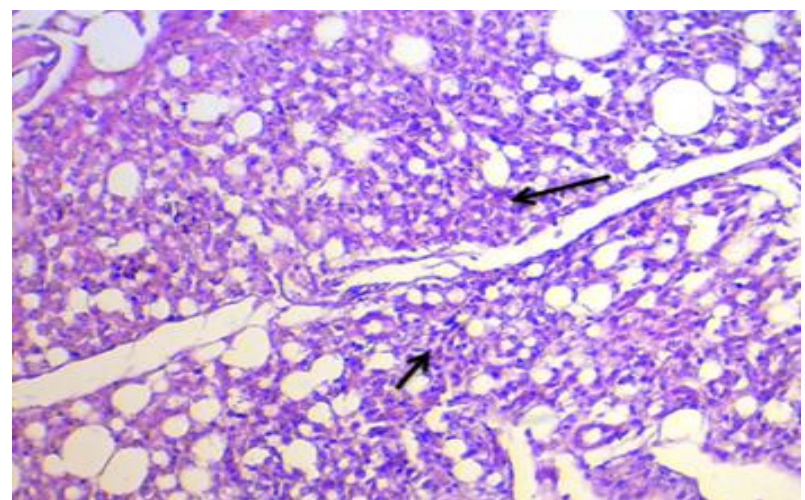

Figure,6: Section of chicken lung tissue showed degeneration of alveolar sac and alveoli and infiltration of lymphocytes (black arrows). There is interstitial infiltration of mononuclear cell in the lung observed around the bronchioles and bronchi. (H\&E stain).

Degenerative necrosis in the epithelial cells, crypts of the mucosa, submucosa, and also in muscular layer were observed in the intestine of infected birds. Duodenum suffered catarrhal enteritis in every sample. Desquamation, necrosis of epithelial mucosal cell, hemorrhage, and inflammatory cell infiltration into submucosal layer were noticed (Fig.7).(A,B)

A

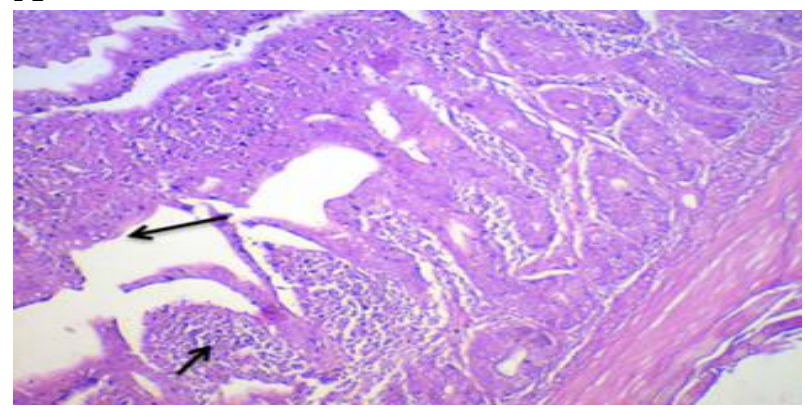

B

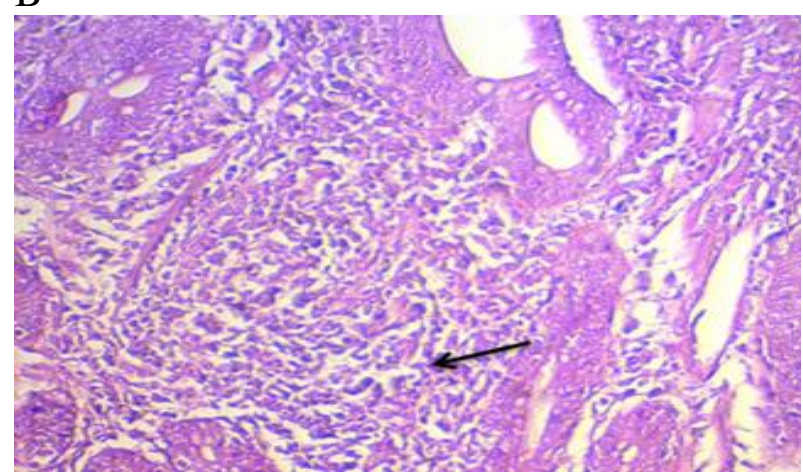

Figure,7: Chicken intestine showed extensive ulceration of intestinal epithelium and infiltration of lymphocytes and macrophages (lack arrows) (A\&B).
Histopathological changes were observed in splenic tissues from infected birds. Severe lymphocyte depletion was noticed in the paranchyma of the spleen. Some other splenic tissues showed focal vacuolation and damage of lymphocytes in the cortical zones and in germinal centres (Fig.8).

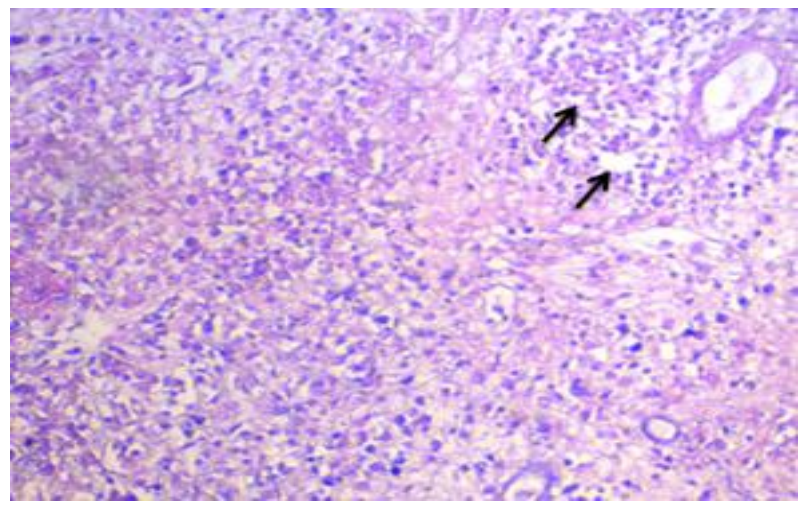

Figure, 8: Chicken spleen shows focal vacuolation and damage of lymphocytes in the cortical zones and in germinal centres (black arrows) (H\&E stain).

Liver tissues from infected birds, showed severe focal infiltration of lymphocytes in the parenchyma of the liver, whereas the hepatocyte showed diffused coagulative necrosis (Fig.9).

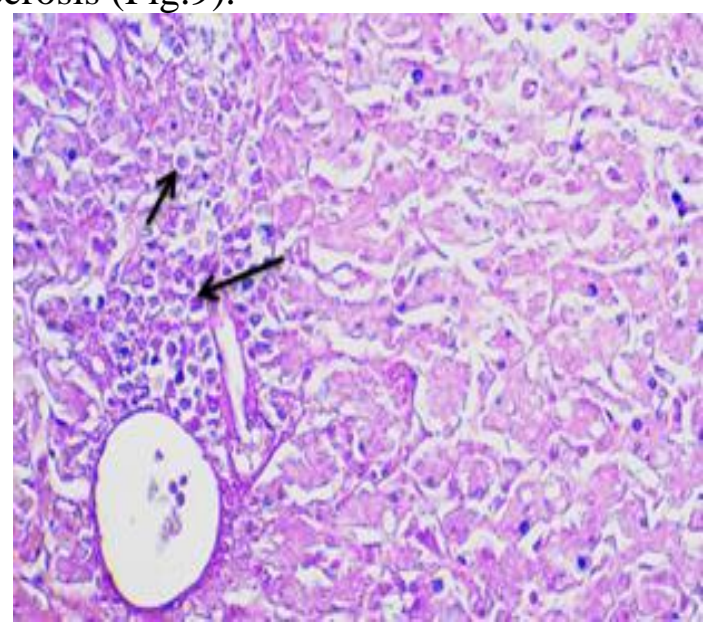

Figure,9: Chicken liver shows degeneration of hepatocytes and infiltration of lymphocytes and macrophages (black arrows) (H\&E stain).

Brain tissues showed hyperemia, perivascular cuffing, edema, gliosis, satellitosis., neuronal degeneration, hypertrophy, oedema and lymphocytic infiltration. (Fig.10).(A,B) 


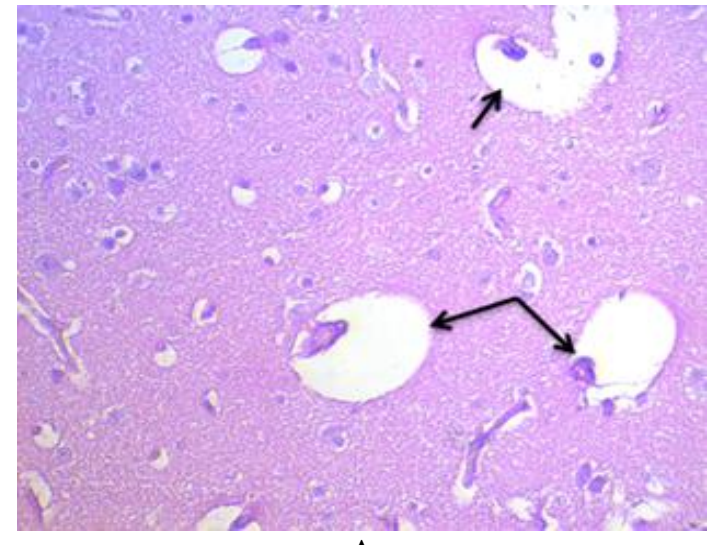

A

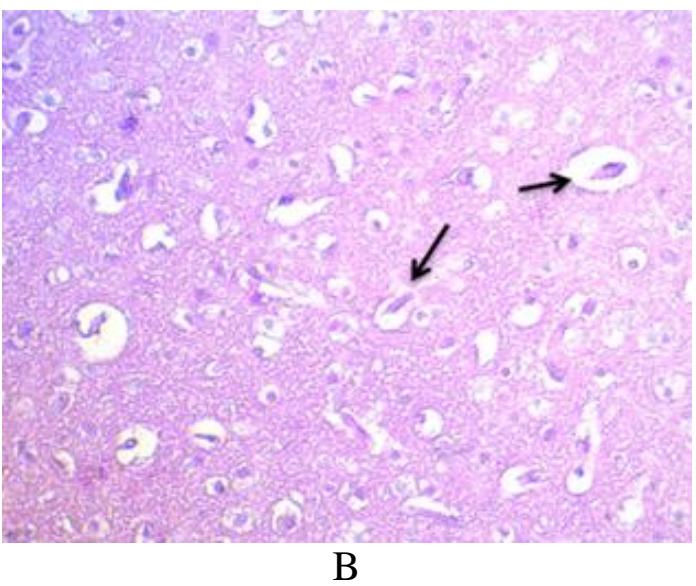

Figure,10:Brain shows neuronal degeneration, hypertrophy, oedema (black arrows A\&B) and lymphocytic infiltration. (H\&E stain).

The hosts play important roles in exposing the severity of NDV. It is well known that chickens are highly susceptible to NDV, whereas ducks might show few or no clinical signs when infected with lethal strains of NDV that was isolated from chicken (25). Hemorrhage, edema and congestion due to vascular disturbances were observed in many organs. Several changes have been observed like endothelial cells necrosis, tunica media hydropic degeneration, arterioles and capillaries hyalinization, capillary thrombosis and endothelial cells necrosis $(23,24,26$ and 27).Many studies reported that NDV could occur in vaccinated birds and depend on the type of vaccine (20) and genotype of the virus (28). Occurring of NDV infection in vaccinated birds was attributed to vaccine failure (29) or to the vaccination with different heterologous genotype (30), as there were sixteen different genotypes (31 and 32).In a final conclusion, the virus of present study seems to be very virulent if compared to circulating viruses and those of NDV vaccines in Diyala province. Accordingly, it clearly appeared that the present vaccine could not offer good and acceptable protection against the natural infection of fowl with virulent NDV. Preparation of NDV vaccine from circulating virulent viral isolate is strongly recommended.

\section{References}

1- MacLaclan N.J., and Dubovi, E.J. (2011). Fenner's Veterinary Virology. $4^{\text {th }}$ ed.Pp:299325. Academic Press. ELSEVER.

2- Ashraf, A. and Shah, M.S. (2014) "Newcastle Disease: Present status and future challenges for developing countries". African J of Microb Res, 8(5): 411-416.

3- Liu, H.L., Wang, Z.L., Wu YG, Wu Yand Sun CY, et al. (2008). "Molecular characterization and phylogenetic analysis of new Newcastle disease virus isolates from the mainland of China". Rese of Vete Scie 85: 612-616.

4- FAO:Faostat.Production.Liveanimals, 2012 http://faostat.fao.org/site/573/default.aspx\#ancor.

5- Huang, Z., Panda, A., Elankumaran, S., Rockemann, D.D. and Samal, S.K. (2004). "The haemagglutination-neuranimidase protein of Newcastle disease virus determines tropism and Virulence". J of Virol, 78:41764184.

6- OIE. (2012). "Newcastle disease, in: OIE terrestrial manual:manual of diagnostic tests and vaccines for terrestrial animals". World Organization for Animal Health. Paris. France.

7- Piancenta, A.M, D.I. King, B.S. Seal, J Zhang and C.C. Brown. (2006). "Pathogenesis of Newcastle disease in commercial and specific pathogen free turkeys experimentally infected with isolates of different virulence". Vet Pathol, 43:168178.

8- Horwitz M.S. and Scharff, M.D. (1969). "The production of antisera against viral antigens". In Habel, $\mathrm{K}$ and Salzman, N.P. Fundamental Techniques in Virology. Pp: 223-262. Academic Press.

9- Alexander, D.J. (2003) “ Newcastle disease and other paramyxovirus infections". In "Disease of poultry "Eds. By Saif, Y.M. Associated with Barnes, H. J., Fadly, A. M., Glisson, J.R., McDongald, L.R. \& Swayne, 
D. E. Jrth. Ed., lowa state University Press, Ames, Lowa, U.S.A. pp: 63- 87.

10-OIE (2008), Chapter 2.3.14 In: Manual of diagnostic tests and vaccines for terrestrial animals, 6th ed., pp: 576-589. OIE, Paris, France.

11- Hanson R.P. (1980). Newcastle disease. In: Isolation and Identification of Avian Pathogens, Hitchner SB., Purchase HG. \& Williams J.E., eds. AAAP, College Station, Texas, USA, pp: 63-66.

12- Al-Kennany A.R. (2012). pathology technology isteds. Deposit number at the national library in Baghdad(2909).

13- Kang-Seuk, C. (2017). "Newcastle disease virus vectored vaccines as bivalent or antigen delivery vaccines". Clin. Exp. Vaccine Res. 6:72-82.

14- Alexander, D.J., Bell, J.G and Alders, R.G. (2004). "A Technology Review: Newcastle Disease-with Special Emphasis on Its Effects on Village Chickens" Chapter 1-3, Food and Agriculture Organization (FAO) of the United Nations, Rome, Italy.

15- Reynolds, D.L. and Maraqa, A.D.( 2000). "Protective immunity against Newcastle disease: the role of cell-mediated immunity". Avian Dis. 44 pp: 145-154.

16- Meulemans, G., Letellier,C., Gonze, M.,Carlier, M. C and Burny, A. (1988). "Newcastle disease virus F glycoprotein expressed from a recombinant vaccinia virus vector protects chickens against live virus challenge". Avian Pathology 17:821 827.

17- Rahman, M.M., Bari, A. S. M., Giasuddin, M. and Islam, M. R., et al. (2002). "Evaluation of Maternal and Humoral Immunity against Newcastle Disease Virus in Chicken". International J of Poultry Scie, 1: 161-163.

18-Rue, C.A., Susta, L., Brown, C.C., Pasick, J.M., Swafford, S.R., Wolf, P.C., Killian, M.L., Pedersen, J.C., Miller, P.J., and Afonso, C.L., (2010). "Evolutionary changes affecting rapid diagnostic of 2008 Newcastle disease viruses isolated from double-crested cormorants". J of Clinical Microbiol 48(7):2440-2448.

19- Miller, P.J. and Koch, G., 2013. Newcastle disease. In: Swayne, D.E., Glisson, J.R., McDougald, L.R., Nolan, L.K., Suarez, D.L., Nair, V. (Eds.), Diseases of Poultry. Wiley-
Blackwell, Hoboken, New Jersey, pp: 89138.

20-Kapczynski, D.R and King,D.J. (2005). "Protection of chicken against overt clinical disease and determinants of viral sheding following vaccination with commercially available Newcastle disease virus vaccine upon challenge with highly virulent virus from California 2002 exotic Newcastle disease outbreak". Vaccine 23: 3424-3433.

21-Alexander, D.J. and Senne, D.A. (2008). "Newcastle disease, other avian paramyxoviruses, and pneumovirus infections In: Disease of poultry, 12th ed. Saif, et al. Blackwell Publishing Professional, Ames, Iowa. Pp :75 - 100.

22- Dauda, G.B. (2009). "Challenge studies in chickens to evaluate the efficacy of commercial Newcastle disease vaccines against the strains of Newcastle disease virus prevalent in South Africa. Thesis for: Master of Science (MSc) Veterinary Science.

23- Bhaiyat, M.I., Ochiai, K., Itakura, C., Islam, M.A. and Kida, H. (1994). Brain lesions in young broiler chickens naturally infected with a mesogenic strain of NDV. Avian Pathology 23: 693-708.

24-Saif, Y. M ; Fadly, A. M; Glisson, J. R and McDougald, L.R (2008). "Newcastle disease, other avian paramyxoviruses, and pneumovirus infections," in Diseases of Poultry, pp: 75-93, Blackwell Publishing Professional, Ames, Iowa, USA, 12th edition.

25- Abdisa T., and Tagesu, T. (2017). Review on Newcastle Disease of Poultry and its Public Health Importance. Journal of Veterinary Science Technology 8:441.

26- Hamid, H., Campbell, R.S.F and Lamichhan, C. (1990). The pathology of infection of chickens with the lentogenic V4 strain of NDV. Avian Pathology 19: 687-696.

27-Etriwati, Ratih, D., Handharyani,E. and Setiyaningsih,S. (2017). "Pathology and immunohistochemistry study of Newcastle disease field case in chicken in Indonesia". Vet World, 10(9): 1066-1071.

28- Farooq, M., Saliha, U., Munir, M., and Khan, Q.M. (2014). "Biological and genotypic characterization of Newcastle disease virus isolated from disease outbreaks in commercial poultry farm in northern Punjab, Pakistan. Virology Reports 3: 30-39. 
29- Dortmans, J.C., Peeters, B.P. and Koch, G. (2012). "Newcastle disease virus outbreaks: Vaccine mismatch or inadequate application. Vet Microb. 160:17-22.

30- Hu, Z., Hu, S., Meng, C., Wang, X., Zhu, J., and Liu, X.( 2011). "Generation of a genotype VII Newcastle disease virus vaccine candidate with high yield in embryonated chicken egg." Avian Diseases 55: 391-397.

31- Courtney, S.C., Susta, L., Gomez, D., Hines, N.L., Pedersen, J.C., Brown, C.C.,Miller, P.J. and Afonso, C.L. (2012). Highly divergent virulent isolates of Newcastle disease virus from the Dominican Republic are members of a new genotype that may have evolved unnoticed for over 2 decades. Journal of Clinical Microbiology, 52: 508-517.

32- Diel, D.G., da Silva, L.H., Liu, H., Wang, Z., Miller, P.J. and Afanso, C.L. (2012). "Genetic diversity of avian paramyxovirus type-1: proposal for a unified nomenclature and classification system of Newcastle disease virus genotypes. Infect. Genet. Evol. 12:1770-1779.

$$
\begin{aligned}
& \text { عزل وتوصيف عزلة ضارية من فيروس مرض نيوكاسل من حقل للاجاج اللاحم في } \\
& \text { محافظة ديالى: دراسة فيروس مرضيروسية ونسجية مرضية من فلية } \\
& \text { عامر خزعل العزاوي و كريم سعدون العجيلي وعلاء اسماعيل }
\end{aligned}
$$

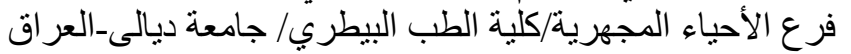

\section{الخلاصة}

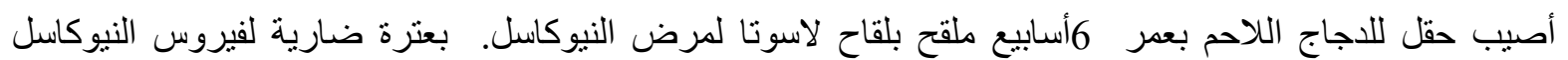

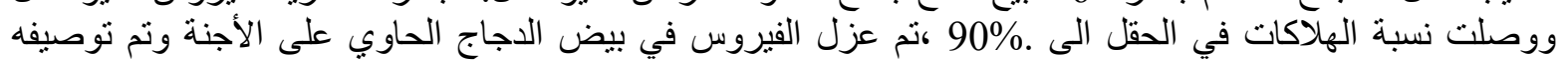

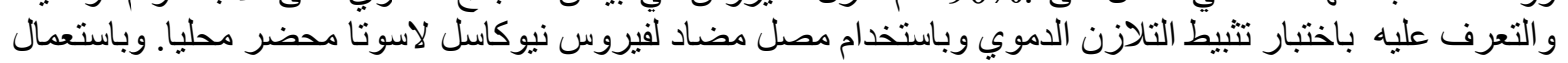

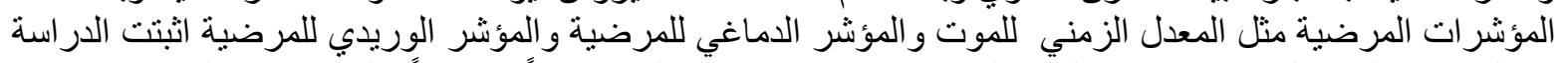

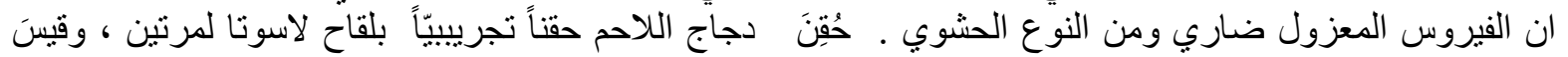

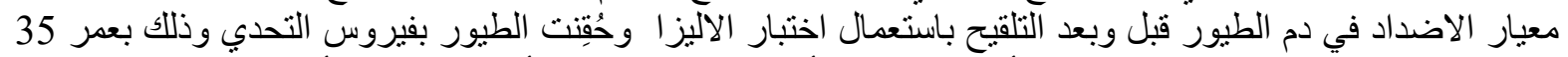

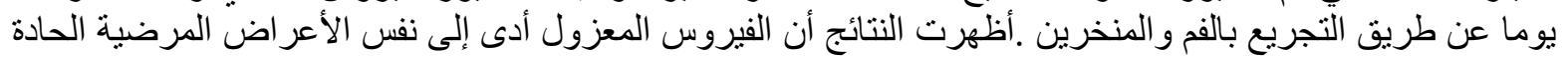

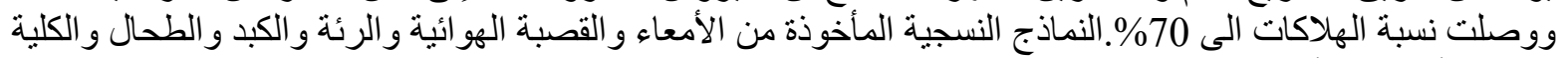

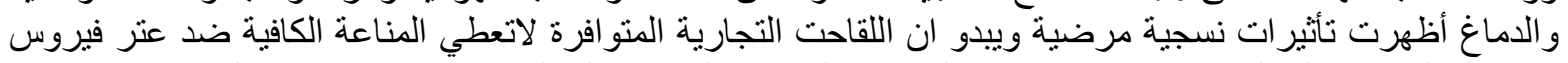

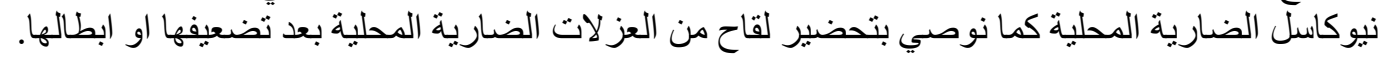

